\title{
METHOD VALIDATION FOR THE DETERMINATION OF EXCHANGEABLE CATIONS IN NATURAL ZEOLITES USING INDUCTIVELY COUPLED PLASMA OPTICAL EMISSION SPECTROMETRY
}

\author{
MARIN SENILA ${ }^{a *}$, OANA CADAR ${ }^{a}$, MARIA-ALEXANDRA HOAGHIA $^{a}$, \\ ZAMFIRA DINCA ${ }^{a}$, LACRIMIOARA SENILA ${ }^{a}$, IOAN ASCHILEAN $^{\mathrm{b}, \mathrm{c}}$, \\ CECILIA ROMANa
}

\begin{abstract}
The paper presents the validation of a method for the determination of exchangeable cations $\left(\mathrm{K}^{+}, \mathrm{Na}^{+}, \mathrm{Ca}^{2+}\right.$ and $\left.\mathrm{Mg}^{2+}\right)$ in zeolites by inductively coupled plasma optical emission spectrometry (ICP-OES), after extraction in ammonium chloride solution. Amongst the analytical techniques that can be used for exchangeable cations measurement, ICP-OES provides rapid, robust, multi-element analysis on a wide range of concentrations. The exchange capacity is one of the most important parameters of zeolites since it indicates their adsorption capacity in different processes. Method validation is an essential requirement for testing laboratories in order to provide trustworthy results in accordance with ISO/IEC 17025:2017 standard. The main figures of merit were studied, and the measurement uncertainty was assessed. The selectivity assay showed no significant non-spectral matrix effect. The linearity study was conducted for the calibration curves in the range of $0.02-20 \mathrm{mg} \mathrm{L}^{-1}$ for each exchangeable cation. Limits of quantification were $0.005 \mathrm{mEq} 100 \mathrm{~g}^{-1}$ for $\mathrm{Na}^{+}, 0.011 \mathrm{mEq} 100 \mathrm{~g}^{-1}$ for $\mathrm{Mg}^{2+}, 0.002 \mathrm{mEq} 100 \mathrm{~g}^{-1}$ for $\mathrm{K}^{+}, 0.003 \mathrm{mEq} 100 \mathrm{~g}^{-1}$ for $\mathrm{Ca}^{2+}$. Relative standard deviations of repeatability (RSDr) ( $\mathrm{n}=6$ parallel samples) were $4.50 \%$ for $\mathrm{Na}^{+}, 4.43 \%$ for $\mathrm{Mg}^{2+}, 6.55 \%$ for $\mathrm{K}^{+}$and $5.53 \%$ for $\mathrm{Ca}^{2+}$. Recoveries (\%) estimated using a certified reference material (CRM BCS-CRM 375/1), for total content of cation oxides were in the range 92-103\%. Fourteen zeolite samples from Racos deposit, Romania were analysed, and according to the chemical composition and Xray diffraction the main mineral in zeolitic tuffs is clinoptilolite-type. The obtained figures of merit demonstrate that the method has a suitable level of precision and accuracy for the intended purpose.
\end{abstract}

Keywords: zeolites, exchangeable cations, ICP-OES, method validation, cation exchange capacity

a INCDO-INOE2000, Research Institute for Analytical Instrumentation, 67 Donath str., RO400293, Cluj-Napoca, Romania

b Zeolites Production S.A., Rupea, Brasov, Romania

c Technical University of Cluj-Napoca, 28 Memorandumului st., 400114, Cluj-Napoca, Romania

* Corresponding author: marin.senila@icia.ro 
MARIN SENILA, OANA CADAR, MARIA-ALEXANDRA HOAGHIA, ZAMFIRA DINCA, LACRIMIOARA SENILA, IOAN ASCHILEAN, CECILIA ROMAN

\section{INTRODUCTION}

Zeolites have physical and chemical properties that make them useful in many applications in domains such as ecology, industrial processes, agronomy, cosmetics and medicine. The name 'zeolite' originates from the Greek words 'zeo' (to boil) and 'litos' (a stone) [1]. Zeolites may be natural, of volcanic origin, or synthetic materials. They have a crystalline structure with a three-dimensional framework formed by repeated units of siliconoxygen $\left(\mathrm{SiO}_{4}\right)$ and aluminum-oxygen $\left(\mathrm{AlO}_{4}\right)$ tetrahedral units, which forms well-defined cavities negatively charged. To maintain the neutrality for the whole structure, the cavities contain positively charged alkali and alkali earth cations such as $\mathrm{K}^{+}, \mathrm{Na}^{+}, \mathrm{Ca}^{2+}$ and $\mathrm{Mg}^{2+}$. The cationic sites of zeolites can be substituted by other cationic species with ionic radius fitting the pore size of internal zeolite framework [2-4].

The exchange capacity is one of the most important properties that influence the zeolites applicability. The higher ability of zeolitic materials to exchange movable $\mathrm{Na}^{+}, \mathrm{K}^{+}, \mathrm{Ca}^{2+}$ and $\mathrm{Mg}^{2+}$ cations is equivalent with their high adsorption capacity in different processes. The amounts of exchangeable cations within zeolites pores/channels strongly depend on Si/Al ratio in its structure, as it influences the negative charge available to attract cations [5].

The cations naturally contained by zeolites may be replaced with other positive ions such as unwanted heavy metals or ammonia ions from industrial effluents [6]. To increase the cation exchange capacity (CEC), natural zeolites can be modified by single or combined treatments such as thermal or chemical activation using acids, bases or inorganic salts $[7,8]$.

There are different approaches regarding the measurement of CEC for crystalline materials. Munthali and co-workers [9] proposed a method based on the measured amount of $\mathrm{Na}^{+}$(sum of retained as $\mathrm{Na}^{+}$and free $\mathrm{Na}^{+}$as $\mathrm{NaCl}$ ), following a modified method used for CEC determination in soil clays. Other approaches formerly used to measure CEC are based on methylene blue (MB) absorption in zeolite, but some authors suggested that the size of MB molecule is generally greater than the pores of zeolitic channels, which can lead to inaccurate results [10].

The ammonium acetate saturation (AMAS) method involves the saturation of zeolites channels with ammonium ions $\left(\mathrm{NH}_{4}{ }^{+}\right)$to replace the exchangeable cations. All $\mathrm{NH}_{4}{ }^{+}$ions adsorbed in zeolite can be considered a measure on CEC [10]. AMAS method was firstly developed to measure the CEC of soil, using for saturation a solution of ammonium acetate $1 \mathrm{~N}$. This method involves the subsequent release of $\mathrm{NH}_{4}{ }^{+}$ions from zeolites and measurement of their concentration in the resulted solution.

Although the cation-exchange capacity laid the foundation for applications in different industries, no international standard method is available 
for the determination of this exchange capacity of zeolites. Also, the literature is very scarce in presenting methods for CEC determination in zeolites.

A methodology to calculate the CEC of zeolites is based on the measurement of the content of the exchanged cations $\left(\mathrm{K}^{+}, \mathrm{Na}^{+}, \mathrm{Ca}^{2+}\right.$, and $\left.\mathrm{Mg}^{2+}\right)$ from zeolite samples by $\mathrm{NH}_{4}{ }^{+}$ion [7]. The measurement of these cations in solution can be carried out using spectrometric, ion chromatographic or titrimetric methods. Amongst the spectrometric methods, those using inductively coupled plasma torch as spectral source (inductively coupled plasma optical emission spectrometry (ICP-OES) and inductively coupled plasma mass spectrometry (ICP-MS)) are preferred due to the advantages of multi-element detection capabilities and wide dynamic range $[11,12]$.

In order to produce reliable analytical results, a laboratory should validate the used methods [13]. The purpose of method validation is to ensure that the analytical methodology is accurate, precise, and robust within a specific domain in which the analyte is determined. The methodologies used for the evaluation of performance parameters should take into account the calibration using reference standards, use of certified reference materials, comparison of results achieved by different methods and estimation of the uncertainty of the results [14-16].

The purpose of this study was to perform validation of a method used for the determination of exchangeable cations in zeolites by ICP-OES after their replacement by $\mathrm{NH} 4+$ ions from an ammonium chloride solution, and to evaluate the measurement uncertainty for this method. The validation was performed considering the recommendations of the Cooperation for Analytical Chemistry in Europe (EURACHEM) guide [17]. This paper represents a model for the method validation in analytical laboratories in order to check the fit for purpose of spectrometric analytical methods.

\section{RESULTS AND DISCUSSION}

\section{Characteristics of the zeolite samples}

In order to evaluate the suitability of a zeolite for a specific application as cation exchange material, the determination of its physical-chemical properties is necessary. The chemical formula of zeolites may be presented as $\mathrm{Me}_{2 / \mathrm{n}} \mathrm{O}$ $\mathrm{Al}_{2} \mathrm{O}_{3} \times \mathrm{SiO}_{2} \mathrm{yH}_{2} \mathrm{O}$, where $\mathrm{Me}$ is an atom of alkali or alkaline earth element, $n$ represent the charge of $M e, x$ is the number of Si tetrahedra, while $y$ is the number of water molecules [1]. The main cations of alkali or alkaline earth elements present in natural zeolites are $\mathrm{K}^{+}, \mathrm{Na}^{+}, \mathrm{Ca}^{2+}$, and $\mathrm{Mg}^{2+}$. Thus, the measurement of exchangeable cations concentrations will provide a good indication of zeolite cation exchange capacity. Knowing the amounts of each cation released by zeolite during the exchange process offers also useful information for intended use of zeolite. 
MARIN SENILA, OANA CADAR, MARIA-ALEXANDRA HOAGHIA, ZAMFIRA DINCA, LACRIMIOARA SENILA, IOAN ASCHILEAN, CECILIA ROMAN

Fourteen natural zeolites samples (Z1-Z14) from a quarry located in Racos, Brasov County, Romania were collected and analyzed. The samples were preliminary characterized regarding chemical composition for major elements using ICP-OES after microwave assisted digestion. Three parallel determinations including digestion and instrumental measurements were carried out for each sample. The measured concentrations of major elements ( $\mathrm{Si}, \mathrm{Al}, \mathrm{Fe}, \mathrm{Na}, \mathrm{K}, \mathrm{Ca}$, and $\mathrm{Mg}$ ) were converted to oxides using atomic and molecular masses [8]. Minimum, maximum, mean, median and standard deviation [18] for each oxide, along with skewness, kurtosis values to evaluate normality of distribution calculated using Statistica version 10 Software [19] are presented in Table 1.

Table 1. Major oxides concentrations (\%) in zeolite samples from the Racos deposit, Romania

\begin{tabular}{|c|c|c|r|r|r|r|r|r|}
\hline Sample & $\mathrm{SiO}_{2}$ & $\mathrm{Al}_{2} \mathrm{O}_{3}$ & \multicolumn{1}{|c|}{$\mathrm{CaO}$} & \multicolumn{1}{|c|}{$\mathrm{MgO}$} & \multicolumn{1}{|c|}{$\mathrm{K}_{2} \mathrm{O}$} & $\mathrm{Na}_{2} \mathrm{O}$ & $\mathrm{Fe}_{2} \mathrm{O}_{3}$ & $\mathrm{MnO}$ \\
\hline $\mathbf{Z 1}$ & 62.95 & 10.29 & 2.50 & 0.72 & 2.32 & 0.40 & 1.39 & 0.02 \\
\hline $\mathbf{Z 2}$ & 58.98 & 9.87 & 2.85 & 0.59 & 2.12 & 0.88 & 1.12 & 0.03 \\
\hline $\mathbf{Z 3}$ & 57.09 & 9.89 & 2.05 & 0.65 & 2.29 & 0.53 & 1.23 & 0.02 \\
\hline $\mathbf{Z 4}$ & 59.09 & 10.55 & 2.75 & 0.54 & 2.18 & 0.81 & 1.04 & 0.03 \\
\hline $\mathbf{Z 6}$ & 63.84 & 10.34 & 2.59 & 0.55 & 2.14 & 0.78 & 1.10 & 0.02 \\
\hline $\mathbf{Z 7}$ & 60.17 & 10.20 & 2.05 & 0.73 & 1.97 & 0.16 & 1.36 & 0.01 \\
\hline $\mathbf{Z 8}$ & 63.75 & 10.22 & 2.28 & 0.72 & 2.14 & 0.21 & 1.15 & 0.01 \\
\hline $\mathbf{Z 9}$ & 62.68 & 10.63 & 2.64 & 0.66 & 2.50 & 0.52 & 1.55 & 0.03 \\
\hline $\mathbf{Z 1 0}$ & 57.32 & 10.74 & 2.19 & 0.71 & 2.50 & 0.42 & 1.41 & 0.14 \\
\hline $\mathbf{Z 1 1}$ & 67.50 & 10.15 & 2.84 & 0.59 & 2.44 & 0.62 & 1.59 & 0.04 \\
\hline $\mathbf{Z 1 2}$ & 65.36 & 11.19 & 2.26 & 0.82 & 2.29 & 0.58 & 1.59 & 0.05 \\
\hline $\mathbf{Z 1 3}$ & 59.30 & 10.72 & 2.12 & 0.73 & 2.20 & 0.53 & 1.43 & 0.03 \\
\hline $\mathbf{Z 1 4}$ & 63.43 & 10.84 & 2.31 & 0.80 & 2.17 & 0.56 & 1.70 & 0.08 \\
\hline Min. & 57.09 & 9.87 & 2.05 & 0.54 & 1.97 & 0.16 & 1.04 & 0.01 \\
\hline Max. & 71.79 & 11.19 & 2.85 & 0.82 & 2.50 & 0.88 & 1.70 & 0.14 \\
\hline Mean & 62.38 & 10.48 & 2.42 & 0.68 & 2.25 & 0.55 & 1.36 & 0.04 \\
\hline Median & 62.81 & 10.45 & 2.40 & 0.70 & 2.25 & 0.55 & 1.40 & 0.03 \\
\hline Stdev. & 4.11 & 0.42 & 0.28 & 0.09 & 0.15 & 0.21 & 0.21 & 0.03 \\
\hline Skewness & 0.791 & 0.231 & 0.186 & -0.185 & 0.145 & -0.346 & -0.114 & 2.356 \\
\hline Kurtosis & 0.637 & -0.783 & -1.431 & -0.777 & -0.379 & -0.214 & -1.138 & 6.025 \\
\hline & & & & & & & \\
\hline
\end{tabular}

The concentrations of $\mathrm{SiO}_{2}$ were in the range of $57.09-71.79 \%$, with a mean value of $62.38 \%$. The concentrations of the other oxides ranged between $9.87-11.19 \% \mathrm{Al}_{2} \mathrm{O}_{3}, 2.05-2.85 \% \mathrm{CaO}, 0.54-0.82 \% \mathrm{MgO}, 1.97-2.50 \%$ $\mathrm{K}_{2} \mathrm{O}, 0.16-0.88 \% \mathrm{Na}_{2} \mathrm{O}, 1.04-1.70 \% \mathrm{Fe}_{2} \mathrm{O}_{3}$ and $0.01-0.14 \% \mathrm{MnO}$. The skewness value indicates the deviation of the distribution from symmetry. When the skewness value significantly differs from 0 , the distribution is asymmetrical, 
while when this value is less than -1 or greater than 1 , the distribution is considered highly asymmetrical $[19,20]$. Except for $\mathrm{MnO}$, the skewness values within the range of -1 to 1 were calculated, indicating a normal distribution. Kurtosis value is associated with the peakedness of a distribution, and its value increases with peakedness and decreases with flatness [20]. The homogeneity of the oxide concentrations was indicated by the closeness between mean and median values, as well as by low values of the standard deviations. These homogenous distributions of different constituents in the samples can be considered an advantage for the exploitation of the zeolitic tuff from this quarry.

Clinoptilolite mineral has a Si/Al ratio higher than 4 and prevailing alkaline cations $(\mathrm{Na}+\mathrm{K}>\mathrm{Ca})$ [21]. The content of the alkaline cations are dominant and indicates that the main mineral in zeolitic tuffs collected from Racos deposit is clinoptilolite-type, with Si/Al ratios ranging between 4.705.86 , and sum of $\mathrm{Na}+\mathrm{K}$ concentrations higher than $\mathrm{Ca}$ concentrations, in all samples. In Figure 1 is presented the XRD pattern of sample Z1.

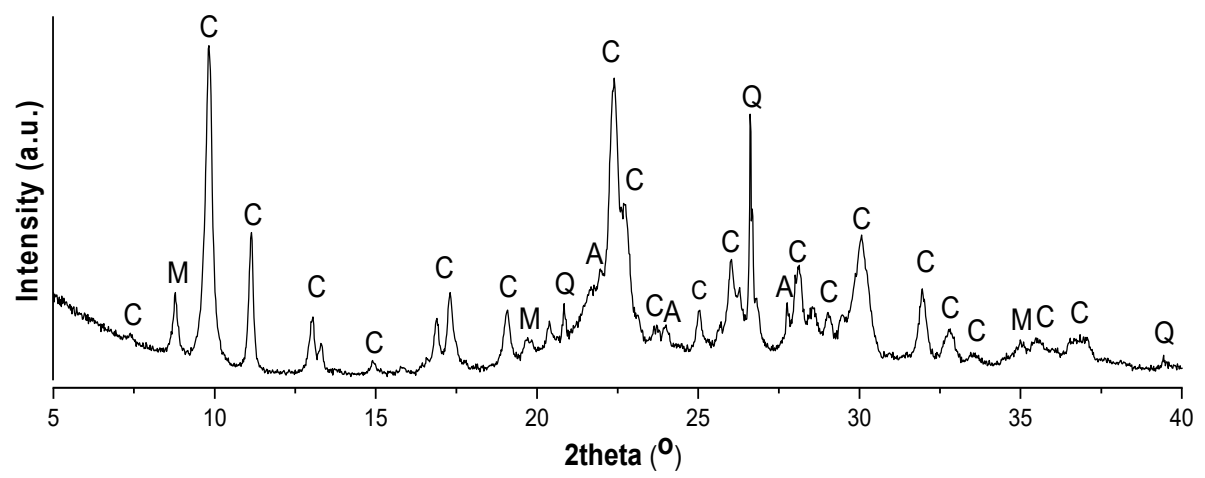

Figure 1. X-ray diffraction pattern of the zeolite sample Z1 from Racos quarry

According to $\mathrm{X}$-ray diffraction analysis, the investigated zeolites from the Racos quarry contain clinoptilolite $\left(C, \mathrm{KNa}_{2} \mathrm{Ca}_{2}\left(\mathrm{Si}_{29} \mathrm{Al}_{7}\right) \mathrm{O}_{72} \cdot 24 \mathrm{H}_{2} \mathrm{O}\right.$, PDF 00-039-1383) as the main crystalline phase, accompanied by quartz ( $Q$; $\mathrm{SiO}_{2}$, PDF 00-005-0490), muscovite $\left(M ; \mathrm{KAl}_{2}\left(\mathrm{AISi}_{3} \mathrm{O}_{10}\right)(\mathrm{OH})_{2}\right.$, PDF 00-0070025) and albite $\left(A, \mathrm{NaAISi}_{3} \mathrm{O}_{8}\right.$, PDF 00-019-1184) in lower concentrations.

\section{Method validation}

The validation of the analytical procedure for determination of exchangeable cations in zeolites by ICP-OES was performed by evaluating the main figures of merit: limit of detection (LoD), limit of quantification (LoQ), working and linear range for each individual cation, trueness/accuracy and 
precision according to the EURACHEM guide [17]. The concentrations of exchangeable cations $\left(\mathrm{Na}^{+}, \mathrm{K}^{+}, \mathrm{Ca}^{2+}\right.$ and $\mathrm{Mg}^{2+}$ ) replaced by $\mathrm{NH}_{4}{ }^{+}$ion from a solution of $\mathrm{NH}_{4} \mathrm{Cl} 1 \mathrm{M}$ were measured by ICP-OES. Inter-cationic exchange capacity was calculated as $\mathrm{mEq} 100 \mathrm{~g}^{-1}$, taking into account measured concentration for each cation in extraction solution and its corresponding gram equivalent, amount of zeolite sample used for extraction $(15 \mathrm{~g})$ and final volume of extract $(250 \mathrm{~mL})$.

\section{Selectivity}

In the determinations of analytes using spectrometric techniques from samples having complex matrices (in this case, extracts form zeolites), spectral and non-spectral interferences may occur as a result of the other elements present in the solid sample, as well as the matrix of extracting solution. Matrix effects were studied by recovery of spikes in the extract samples, by adding a spike of $10 \mathrm{mg} \mathrm{L}^{-1}$ of each element to the original samples. The recoveries were within $90 \%$ and $110 \%$, for all the elements.

\section{LoD and LoQ for exchangeable cations}

LoD was estimated from the calibration function for an average net signal resulted from measurement of 10 independent reagent blank solutions containing $1 \mathrm{M} \mathrm{NH}_{4} \mathrm{Cl}$, measured once each, on the same day and three times its standard deviation. LoQ was estimated from the calibration function for a signal equal to the net signal of blank and ten times its standard deviation $[17,22]$. In order to experimentally confirm LoQ, six extracting solution with concentrations close to the LoQ were prepared and analysed. The targeted repeatability expressed as relative standard deviation (RSD) and targeted recovery were $20 \%$ and $90-115 \%$, respectively. Data in Table 2 shows the LoD, LoQ and the measured RSD and recovery for LoQ confirmation.

Table 2. $L O D$ and $L O Q$ for exchangeable cations in extracting solution $1 \mathrm{M} \mathrm{NH}_{4} \mathrm{Cl}$ by ICP-OES

\begin{tabular}{|c|c|c|c|c|c|}
\hline Element & $\boldsymbol{\lambda} \mathbf{( n m )}$ & $\begin{array}{c}\text { LoD } \\
\left(\mathbf{m g ~ L}^{-1}\right)\end{array}$ & $\begin{array}{c}\text { LoQ } \\
\left(\mathbf{m g ~ L}^{-1}\right)\end{array}$ & $\begin{array}{c}\text { RSD at LoQ } \\
(\mathbf{\%})\end{array}$ & $\begin{array}{c}\text { Recovery at } \\
\text { LoQ } \mathbf{~ \% )}\end{array}$ \\
\hline $\mathrm{Na}$ & 589.592 & 0.021 & 0.070 & 8.84 & 109 \\
\hline $\mathrm{Mg}$ & 285.213 & 0.025 & 0.083 & 7.63 & 94.2 \\
\hline $\mathrm{K}$ & 766.490 & 0.014 & 0.047 & 10.8 & 95.6 \\
\hline $\mathrm{Ca}$ & 317.933 & 0.011 & 0.037 & 8.46 & 92.5 \\
\hline
\end{tabular}

Considering the LoQ values for cations in extraction solution measured by ICP-OES, the corresponding LoQs expressed as exchange capacity taking into account the extraction procedure were calculated to be $0.005 \mathrm{mEq} 100 \mathrm{~g}^{-1}$ 
for $\mathrm{Na}^{+}, 0.011 \mathrm{mEq} 100 \mathrm{~g}^{-1}$ for $\mathrm{Mg}^{2+}, 0.002 \mathrm{mEq} 100 \mathrm{~g}^{-1}$ for $\mathrm{K}^{+}, 0.003 \mathrm{mEq}$ $100 \mathrm{~g}^{-1}$ for $\mathrm{Ca}^{2+}$, while LoQ for sum of exchangeable cations in zeolite sample was estimated to be $0.021 \mathrm{mEq} 100 \mathrm{~g}^{-1}$. Generally the natural zeolites have much higher amounts of exchangeable cations than the calculated LoQs, thus the investigated method is adequate for the intended purpose [22-25].

\section{Working and linear range}

In the case of spectrometric techniques, the working range is the domain of concentrations over which the method is linear for a specific analyte. At the lower part of the working range, the limiting factor is given by LoQ, while at the superior part, the limitations are imposed by the instrument analytical response. Linearity was evaluated from the regression function of calibration using 7 standards, the lowest concentration close to the LoQ, and the higher concentration of $20 \mathrm{mg} \mathrm{L}^{-1}$ for each element. In order to check the homogeneity of variances, 6 measurements at the lowest and at the highest concentrations of calibration curves were measured, and the standard deviations $\left(s_{1}\right)$ and $\left(s_{7}\right)$ were calculated [26]. Using these values, the $P G$ ratios calculated as $s_{1}{ }^{2} / s_{7}{ }^{2}$ or $\mathrm{S}_{7}{ }^{2} / \mathbf{S}_{1}{ }^{2}$ were compared with the critical value Fischer $\mathrm{F}_{5 ; 5 ; 0.99}=11$.

The values for intercept (a), slope (b), correlation coefficient $(R), P G$ ratio and standard error of the regression $\left(S_{\times 0}\right)$ are presented in Table 3.

Table 3. Characteristics of the calibration curves for the working range $0.02-20 \mathrm{mg} \mathrm{L}^{-1}$ using ICP-OES

\begin{tabular}{|c|r|r|r|c|c|}
\hline Element & Intercept (a) & Slope (b) & PG & $\begin{array}{c}\text { Correlation } \\
\text { coefficient (R) }\end{array}$ & $\mathbf{S}_{\mathbf{x} \mathbf{0}}$ \\
\hline $\mathrm{Na}$ & 302536 & 1082123 & 7.33 & 0.9999 & 0.070 \\
\hline $\mathrm{Mg}$ & 2036 & 175305 & 4.31 & 0.9999 & 0.061 \\
\hline $\mathrm{K}$ & 188793 & 556877 & 5.22 & 0.9999 & 0.101 \\
\hline $\mathrm{Ca}$ & 8740 & 20701 & 8.64 & 0.9998 & 0.120 \\
\hline
\end{tabular}

The experimental data showed that variances are homogenous, and the correlation coefficients are much higher than 0.997 , therefore linear regression can be used.

\section{Precision}

Internal repeatability for the measurement of exchangeable cations was evaluated by analysis of 6 parallel zeolite samples, including extraction step, performed by a single operator using the same equipment. The set targets were relative standard deviation of repeatability (RSDr) below $10 \%$ and limit of repeatability $(r)$ below $28 \%$. 
MARIN SENILA, OANA CADAR, MARIA-ALEXANDRA HOAGHIA, ZAMFIRA DINCA, LACRIMIOARA SENILA, IOAN ASCHILEAN, CECILIA ROMAN

The obtained data, showed in Table 4, indicate that standard deviation of repeatability/limit of repeatability were better than the imposed limits for all the analysed cations.

Table 4. Results from the repeatability study ( $n=6$ parallel zeolite samples) using ICP-OES after microwave assisted digestion

\begin{tabular}{|c|c|c|c|c|}
\hline Element & Average (mg/L) & $\mathbf{S}_{\mathbf{r}} \mathbf{( m g / L )}$ & $\mathbf{R S D}_{\mathbf{r}} \mathbf{( \% )}$ & $\mathbf{r} \mathbf{~ ( \% )}$ \\
\hline $\mathrm{Na}^{+}$ & 154 & 6.93 & 4.50 & 12.6 \\
\hline $\mathrm{Mg}^{2+}$ & 35.3 & 1.92 & 5.43 & 15.2 \\
\hline $\mathrm{K}^{+}$ & 705 & 46.2 & 6.55 & 18.3 \\
\hline $\mathrm{Ca}^{2+}$ & 742 & 41.0 & 5.53 & 15.5 \\
\hline
\end{tabular}

$\mathrm{Sr}$ - standard deviation of repeatability; $\mathrm{RSD}_{\mathrm{r}}$ - relative standard deviation of repeatability; $r$ - limit of repeatability $\left(2.8 x R S D_{r}\right)$

\section{Trueness}

The most frequent approach to estimate trueness is to evaluate recovery from analysis of CRMs or spiked samples. Since no CRM having certified values for exchangeable cations in zeolites or other silicate materials are available, in our study we evaluated the recovery using a CRM (BCS-CRM $375 / 1$ soda feldspar) with certified values for total content of $\mathrm{Na}_{2} \mathrm{O}, \mathrm{K}_{2} \mathrm{O}, \mathrm{CaO}$, and $\mathrm{MgO}$. Accurate data for this determination gives indication mainly about reliability of instrumental determination of $\mathrm{Na}^{+}, \mathrm{K}^{+}, \mathrm{Ca}^{2+}$ and $\mathrm{Mg}^{2+}$ by ICP-OES. The results obtained in the analysis of CRM presented in Table 5 indicate good recoveries in the range of $92-103 \%$. These recovery values were in the range of $80-120 \%$ recommended by Association of Official Agricultural Chemists (AOAC) [27] for spectrometric methods. This shows the lack of systematic errors and proves that the proposed method is reliable and free of non-spectral effects.

Table 5. Certified values of CRM BCS-CRM 375/1 soda feldspar, measured values by ICP-OES ( $\mathrm{n}=6$ parallel determinations) and the recoveries $(\%)$

\begin{tabular}{|c|c|c|c|}
\hline Components & $\begin{array}{c}\text { Certified Values } \mathbf{\pm} \mathbf{U} \\
(\%)\end{array}$ & $\begin{array}{c}\text { Measured Values } \pm \mathbf{U}^{*} \\
(\%)\end{array}$ & $\begin{array}{c}\text { Recovery } \mathbf{\pm} \mathbf{U}^{*} \\
(\%)\end{array}$ \\
\hline $\mathrm{Na}_{2} \mathrm{O}$ & $8.89 \pm 0.11$ & $9.06 \pm 0.62$ & $102 \pm 7$ \\
\hline $\mathrm{K}_{2} \mathrm{O}$ & $1.47 \pm 0.03$ & $1.37 \pm 0.12$ & $93 \pm 8$ \\
\hline $\mathrm{MgO}$ & $0.180 \pm 0.016$ & $0.185 \pm 0.018$ & $103 \pm 10$ \\
\hline $\mathrm{CaO}$ & $0.78 \pm 0.03$ & $0.72 \pm 0.07$ & $92 \pm 9$ \\
\hline
\end{tabular}

${ }^{*} \mathrm{U}$ is the expanded uncertainty for $95 \%$ confidence level $(\mathrm{k}=2)$ 
In order to evaluate the agreement between certified and measured values in CRM, the combined uncertainty $(U \Delta)$ was calculated from the specified uncertainty $\left(\mathrm{U}_{\mathrm{CRM}}\right)$ and measured uncertainty $\left(\mathrm{U}_{\mathrm{m}}\right)$ expressed as standard deviation, as well as the difference between average measured concentration $\left(\mathrm{C}_{\mathrm{m}}\right)$ and the certified values $\left(\mathrm{C}_{\mathrm{CRM}}\right)$. The difference between the certified and measured value of each analyte was lower than the combined uncertainty.

Also, an extraction solution of $\mathrm{NH}_{4} \mathrm{Cl} 1 \mathrm{M}$ fortified with $10 \mathrm{mg} \mathrm{L}^{-1}$ of each cation was analysed. The recoveries were within $90 \%$ and $110 \%$ for all the four cations. These results also confirm the lack of non-spectral effects for the proposed method.

\section{Estimation of measurement uncertainty}

The main sources of uncertainty of this method are: uncertainty of reference materials used for instrument calibration, uncertainty of dilutions for preparation of reference solutions and samples, uncertainty of the calibration curves, uncertainty of samples weighting, and repeatability of the replicate analysis. The uncertainty budget for each individual cation and the main sources of uncertainty with their contribution to composed uncertainty are presented in Table 6.

Table 6. Uncertainty budget for exchangeable cations and cation exchange capacity (CEC) determination in zeolite samples

\begin{tabular}{|c|c|c|c|c|c|}
\hline $\begin{array}{c}\text { Sources / relative standard } \\
\text { uncertainty }\end{array}$ & Unit & $\mathrm{Na}^{+}$ & $\mathrm{Mg}^{2+}$ & $\mathrm{K}^{+}$ & $\mathrm{Ca}^{2+}$ \\
\hline Calibration standard & - & 0.006 & 0.006 & 0.006 & 0.006 \\
\hline Standards dilution & - & 0.013 & 0.013 & 0.013 & 0.013 \\
\hline Weighting & - & 0.0001 & 0.0001 & 0.0001 & 0.0001 \\
\hline Sample dilution & - & 0.0022 & 0.0022 & 0.0022 & 0.0022 \\
\hline Calibration curve & - & 0.0070 & 0.0061 & 0.0101 & 0.0120 \\
\hline Repeatability & - & 0.0450 & 0.0543 & 0.0655 & 0.0553 \\
\hline Relative composed uncertainty $\left(\mathrm{u}_{\mathrm{c}}\right)$ & $\%$ & 4.8 & 5.6 & 6.8 & 5.8 \\
\hline $\begin{array}{l}\text { Relative expanded uncertainty }(\mathrm{U}) \\
\mathrm{U}=2 \mathrm{x} \mathrm{u}_{\mathrm{c}}(95 \% \text { confidence interval) }\end{array}$ & $\%$ & 9.5 & 11.3 & 13.5 & 11.7 \\
\hline
\end{tabular}

\section{Exchangeable cations in zeolite samples}

The exchangeable cations measured by ICP-OES in the extracting solution after their replacement by ammonium ion are given in Table 7. 
MARIN SENILA, OANA CADAR, MARIA-ALEXANDRA HOAGHIA, ZAMFIRA DINCA, LACRIMIOARA SENILA, IOAN ASCHILEAN, CECILIA ROMAN

Table 7. Exchangeable cations and cation exchange capacity (CEC) in zeolite samples from the Racos deposit, Romania

\begin{tabular}{|c|c|c|c|c|c|}
\hline \multirow{2}{*}{ Sample } & $\mathrm{Na}^{+}$ & $\mathrm{Mg}^{2+}$ & $\mathbf{K}^{+}$ & $\mathrm{Ca}^{2+}$ & CEC \\
\hline & \multicolumn{5}{|c|}{$\mathrm{mEq} 100 \mathrm{~g}^{-1}$} \\
\hline Z1 & 13.1 & 4.2 & 21.1 & 67.8 & 116.2 \\
\hline Z2 & 28.9 & 2.7 & 31.2 & 79.6 & 142.4 \\
\hline Z3 & 15.6 & 4.0 & 30.9 & 59.1 & 109.6 \\
\hline Z4 & 25.7 & 2.5 & 41.5 & 82.2 & 151.9 \\
\hline $\mathbf{Z 5}$ & 25.0 & 2.5 & 31.2 & 79.6 & 138.2 \\
\hline Z6 & 4.3 & 3.7 & 29.8 & 63.3 & 101.2 \\
\hline $\mathbf{Z 7}$ & 7.1 & 2.6 & 31.2 & 51.3 & 92.1 \\
\hline Z8 & 15.4 & 1.9 & 33.6 & 53.2 & 104.1 \\
\hline Z9 & 20.4 & 3.7 & 29.1 & 77.8 & 130.9 \\
\hline $\mathrm{Z10}$ & 11.2 & 4.8 & 30.1 & 61.8 & 107.9 \\
\hline $\mathrm{Z11}$ & 17.8 & 1.7 & 31.4 & 69.2 & 119.9 \\
\hline Z12 & 15.0 & 4.4 & 26.9 & 66.0 & 112.3 \\
\hline Z13 & 15.7 & 4.4 & 26.7 & 67.6 & 114.5 \\
\hline Z14 & 15.8 & 3.8 & 29.5 & 69.0 & 118.1 \\
\hline Min. & 4.3 & 1.7 & 21.1 & 51.3 & 92.1 \\
\hline Max. & 28.9 & 4.8 & 41.5 & 82.2 & 151.9 \\
\hline Mean & 16.5 & 3.4 & 30.3 & 67.7 & 118.5 \\
\hline Median & 15.6 & 3.7 & 30.5 & 67.7 & 115.4 \\
\hline Stdev. & 6.8 & 1.0 & 4.4 & 9.6 & 16.8 \\
\hline Skewness & 0.145 & -0.268 & 0.608 & -0.086 & 0.591 \\
\hline Kurtosis & -0.106 & -1.661 & 3.764 & -0.756 & -0.215 \\
\hline
\end{tabular}

According to the obtained data, showed in Table 7, the total intercationic exchange capacity varied in the range of $92.1-151.9 \mathrm{mEq} 100 \mathrm{~g}^{-1}$, with an average value of $118.5 \mathrm{mEq} 100 \mathrm{~g}^{-1}$, which means a high exchange capacity of the studied zeolites. The main contribution to the total inter-cationic exchange capacity is due to the $\mathrm{Ca}^{2+}$ (in average $57 \%$ of the $\mathrm{CEC}$ ), $\mathrm{K}^{+}$has an average contribution of $25.9 \%$ of the IEC, $\mathrm{Na}^{+} 13.5 \%$ of the CEC, while $\mathrm{Mg}^{2+}$ has an average contribution to CEC of only $2.9 \%$. The release of low amounts of $\mathrm{Mg}$ suggests that $\mathrm{Mg}$ may be fixed in zeolite, and is not totally released into extracting solution.

Skewness values within the range of -1 to 1 indicate normal distributions for all analysed exchangeable cations. Relatively low values of the standard deviations for the exchangeable $\mathrm{Mg}^{2+}, \mathrm{K}^{+}, \mathrm{Ca}^{2+}$ (below $30 \%$, if calculated as relative standard deviations) indicate good homogeneity of distributions for these cations. However, in case of exchangeable $\mathrm{Na}^{+}$the standard deviation was over $40 \%$ (expressed as relative standard deviation), indicating a variable release of this cation into the extracting solution. 
An increased inter-cationic exchange capacity is required when using natural zeolites in green decontamination technologies that are based on the ion exchange behavior. In this process, the zeolite exchangeable cations are replaced at the sites by other cations from contaminated media [28]. Thus, zeolites with high exchange capacity are desirable for removal of toxic metals cations $\left(\mathrm{Cu}^{2+}, \mathrm{Zn}^{2+}, \mathrm{Cd}^{2+}, \mathrm{Hg}^{2+}, \mathrm{Pb}^{2+}, \mathrm{Cr}^{3+}, \mathrm{Mn}^{2+}, \mathrm{Co}^{2+}, \mathrm{Ni}^{2+}\right.$, etc. $)$ and ammonium cation from wastewaters $[29,30]$.

Belchinskaya et al. [31] reported variable quantities of exchangeable cations desorbed from a natural zeolite form the Sokirnitsa deposit, Ukraine, in the range of $56.7-190.1$ meq $100 \mathrm{~g}^{-1}$, influenced by concentration of ammonium solution used for extraction. Cerri et al. analysed 20 samples of clinoptilolite-bearing rocks from Sardinia, Italy and reported values in the

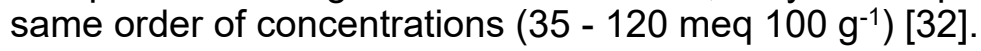

\section{CONCLUSIONS}

Fully validated method for exchangeable cations analysis in zeolites after extraction in $\mathrm{NH}_{4} \mathrm{Cl}$ solution is presented. The fast and precise ICP-OES technique allows the quantification of selected cations in this type of samples. The performance parameters (LOD and LOQ, selectivity, working and linear range, accuracy, precision and measurement uncertainty) satisfied the imposed targets. The method was successfully used for the determination of exchangeable cations in zeolite samples. It provides useful data regarding total cation exchange capacity, and also gives information about the amount of each individual cation released in extracting solution. The results attained by physical-chemical methods showed that the zeolitic tuffs from the Racos deposit, Romania is clinoptilolite-type and have high exchange capacity.

\section{EXPERIMENTAL SECTION}

\section{Materials}

ICP multi-elemental standard solution IV $1000 \mathrm{mg} \mathrm{L}-1$ and monoelement standard solution Si $1000 \mathrm{mg} \mathrm{L-1}$ purchased form Merck (Darmstadt, Germany) were used for ICP-OES calibration. HNO3 65\%, $\mathrm{HCl} 37 \%$, and HF $40 \%$, p.a. obtained from Merck (Darmstadt, Germany) were used for samples digestion or to prepare calibration solutions. Ammonium chloride $\geq 99.5 \%$ from Merck (Darmstadt, Germany) was used to prepare the extracting solution $\mathrm{NH} 4 \mathrm{Cl} 1 \mathrm{M}$. For all dilutions ultrapure water $(18 \mathrm{M} \Omega \mathrm{cm}-1)$ obtained from a Millipore Direct Q3 (Millipore, France) was used. Certified reference material 
MARIN SENILA, OANA CADAR, MARIA-ALEXANDRA HOAGHIA, ZAMFIRA DINCA, LACRIMIOARA SENILA, IOAN ASCHILEAN, CECILIA ROMAN

CRM BCS-CRM 375/1 soda feldspar from Bureau of Analysed Samples Ltd (United Kingdom) was analyzed for the recovery study. Fourteen natural zeolites samples (Z1-Z14) were collected from a quarry located in Racos, Brasov County, Romania.

\section{Sample preparation and instrumentation}

For the determination of total contents of elements in zeolites, $0.25 \mathrm{~g}$ sample, with grain size $<100 \mu \mathrm{m}$, was digested with a mixture of $3 \mathrm{~mL} \mathrm{HNO}_{3}$ $65 \%, 9 \mathrm{~mL} \mathrm{HCl} 37 \%$, and $2 \mathrm{~mL} \mathrm{HF} 40 \%$, in a closed-vessel MWS-3+ microwave system (Berghof, Germany). A three steps digestion program was applied: (1) $10 \mathrm{~min}$ at $200{ }^{\circ} \mathrm{C}$, (2) $30 \mathrm{~min}$ at $220^{\circ} \mathrm{C}$, (3) $15 \mathrm{~min}$ at $100^{\circ} \mathrm{C}$. After cooling 2 grams of $\mathrm{H}_{3} \mathrm{BO}_{3}$ was added and vessels were heat again at $220{ }^{\circ} \mathrm{C}$ for 30 minutes. The resulting solutions were cooled and diluted to $100 \mathrm{~mL}$ with ultrapure water. In order to avoid contamination digestion vessels were precleaned with $10 \%(\mathrm{v} / \mathrm{v}) \mathrm{HNO}_{3}$.

The mineralogy and crystallinity of zeolite were investigated by X-ray diffraction method using a Bruker D8 Advance diffractometer using CuK $\alpha$ radiation ( $\lambda=1.54056 \AA)$ and LynxEye detector, operated at $40 \mathrm{kV}$ and $40 \mathrm{~mA}$.

As no standard method for the determination exchangeable cations in zeolites is available, in this study we used a modification of several methods based on the replacement of $\mathrm{K}^{+}, \mathrm{Na}^{+}, \mathrm{Ca}^{2+}$, and $\mathrm{Mg}^{2+}$ ions from zeolite by $\mathrm{NH}_{4}{ }^{+}$from $\mathrm{NH}_{4} \mathrm{Cl}$ solution, presented in previous published works [31,32]. A ratio of solid / liquid ratio 1:10 was chosen to ensure enough amount of $\mathrm{NH}_{4}{ }^{+}$ to remove in solution the exchangeable cations. For determination of exchangeable cations, $15 \pm 0.01 \mathrm{~g}$ zeolite sample with grain size $<100 \mu \mathrm{m}$ was weighted in a Berzelius beaker, then $150 \mathrm{~mL} \mathrm{NH}_{4} \mathrm{Cl} 1 \mathrm{M}$ were added. The mixture was shaken for $1 \mathrm{~h}$ on a magnetic stirrer, and the insoluble part was filtered through $0.45 \mu \mathrm{m}$ Whatman cellulose membrane filters (Amersham, United Kingdom) and the filtrate was collected in a volumetric flask and diluted up to $250 \mathrm{~mL}$ with ultrapure water. The amounts of $\mathrm{Na}^{+}, \mathrm{K}^{+}, \mathrm{Ca}^{2+}$ and $\mathrm{Mg}^{2+}$ replaced by $\mathrm{NH}_{4}{ }^{+}$ion in this solution were measured using ICP-OES. Three parallel extractions were done for each sample.

\section{Instrumentation}

Analyses were carried out using a dual viewing inductively coupled plasma optical emission spectrometer Optima 5300DV (Perkin Elmer, USA). The operating conditions used for ICP-OES determination were $1300 \mathrm{~W}$ RF power, $15 \mathrm{~L} \mathrm{~min}-1$ plasma Ar flow, $2.0 \mathrm{~L} \mathrm{~min}^{-1}$ auxiliary Ar flow, $0.8 \mathrm{~L} \mathrm{~min}{ }^{-1}$ nebulizer Ar flow, and $1.5 \mathrm{~mL} \mathrm{~min}^{-1}$ sample uptake rate. Axial view and external calibration (7-point linear calibration curve over the range $0-20 \mathrm{mg} \mathrm{L}^{-1}$ element in $4 \% \mathrm{HNO}_{3}$ ) were used for metals determination. 
METHOD VALIDATION FOR THE DETERMINATION OF EXCHANGEABLE CATIONS ...

\section{ACKNOWLEDGMENTS}

The work has been funded by the Competitiveness Operational Programme of the Ministry of European Funds through the Contract No. 7/01.09.2016, code MySMIS 105654.

\section{REFERENCES}

1. S. Kraljevic Pavelic; J. Simovic Medica; D. Gumbarevic; A. Filosevic; N. Przulj; K. Pavelic; Front. Pharmacol., 2018, 9, 1350.

2. B. Calvo; L. Canoira; F. Morante; J.M. Martinez-Bedia; C. Vinagre; J.E. GarciaGonzalez; J. Elsen; R. Alcantara; J. Hazard. Mater., 2009, 166, 619-627.

3. M. Senila; O. Cadar; L. Senila; A. Hoaghia; I. Miu; Molecules, 2019, 24, 4023.

4. M. Hong; L. Yu; Y. Wang; J. Zhang; Z. Chen; L. Dong; Q. Zan; R. Li; Chem. Eng. J., 2019, 359, 363-372.

5. A. Mastinu; A. Kumar; G. Maccarinelli; S.A. Bonini; M. Premoli; F. Aria; A. Gianoncelli; M. Memo; Molecules, 2019, 27, 1517.

6. M. Mudasir; K. Karelius; N.H, Aprilita, E.T. Wahyuni; J. Environ. Chem. Eng., 2016, 4, 1839-1849.

7. S.A. Maicaneanu; H. Bedelean; Studia UBB Chemia, 2020, LXV, 3, 89-100.

8. O. Cadar; M. Senila; M.A. Hoaghia; D. Scurtu; I. Miu; E.A. Levei; Molecules, 2020, 25, 2570.

9. M.W. Munthali; P. Kabwadza-Corner; E. Johan, N. Matsue; J. Mater. Sci. Chem. Eng., 2014, 2, 1-5.

10. K. Kitsopoulos; Clays Clay Miner., 1999, 47, 688-696.

11. E. Covaci; M. Senila; M. Ponta; T. Frentiu; Rev. Roum. Chim., 2020, 65, 735-745.

12. T. Frentiu; M. Ponta.; M. Senila; A.I. Mihaltan.; E. Darvasi; M. Frentiu; E. Cordos; J. Anal. At. Spectrom., 2010, 25, 739-742.

13. M. Senila; E. Levei; L. Senila; O. Cadar; G. Oprea; C. Roman; Studia UBB Chemia, 2011, 56, 27.

14. A. Tudorache; D.E. Ionita; N.M. Marin; C. Marin; I.A. Badea; Accred. Qual Assur., 2017, 22, 29-35.

15. M. Senila; E. Covaci; O. Cadar; M. Ponta; M. Frentiu; T. Frentiu; Chem. Pap., 2018, 72, 441-448.

16. T. Frentiu; S. Butaciu; E. Darvasi; M. Ponta; M. Senila; D. Petreus; M. Frentiu; Anal. Methods., 2015, 7, 747-752.

17. B. Magnusson; U. Ornemark (eds.) Eurachem Guide: The Fitness for Purpose of Analytical Methods - A Laboratory Guide to Method Validation and Related Topics, (2nd ed. 2014), available from https://www.eurachem.org/images/ stories/Guides/pdf/MV_guide_2nd_ed_EN.pdf, accessed on 18.03.2021. 
MARIN SENILA, OANA CADAR, MARIA-ALEXANDRA HOAGHIA, ZAMFIRA DINCA,

LACRIMIOARA SENILA, IOAN ASCHILEAN, CECILIA ROMAN

18. M. Senila; J. Environ. Health Sci. Eng., 2014, 12, 108.

19. StatSoft, Inc. (2011). STATISTICA (data analysis software system), version 10. www.statsoft.com.

20. M.K. Cain; Z. Zhang; K.H. Yuan; Behav. Res., 2017, 49, 1716-1735.

21. D. Bish; J. Boak; Rev. Mineral. Geochem., 2001, 45, 207-216.

22. A. Drolc; A. Pintar; Accreditation Qual. Assur., 2012, 17, 323-330.

23. N. Eroglu; M. Emekci; C.G. Athanassiou; J. Sci. Food Agric., 2017, 97, 34873499.

24. B. Hudcova; M. Osacky; M. Vítkova; A. Mitzia; M. Komarek; Microporous Mesoporous Mater., 2021, 317, 111022.

25. J.A. Ricardo-Garcia; Y. Enamorado-Horrutiner; G. Rodriguez-Fuentes; M.S. Pomares-Alfonso; M.E. Villanueva-Tagle; Microchem. J., 2021, 164, 106064.

26. International organization for standardization (1990) ISO 8466-1 Water quality. Calibration and evaluation of analytical methods and estimation of performance characteristics - Part I: Statistical evaluation of the linear calibration function, Geneva, Switzerland.

27. Chemical Methods for Dietary Supplements and Botanicals. (2002) https://www.aoac.org/aoac_prod_imis/AOAC_Docs/StandardsDevelopment/ SLV_Guidelines_Dietary_Supplements.pdf (accessed May 2021).

28. M. Moshoeshoe; M.S. Nadiye-Tabbiruka; V.O. Moshoeshoe; Am. J. Mater. Sci., 2017, 7, 196-221.

29. D. Kallo; Rev. Mineral. Geochem., 2001, 45, 519-550.

30. E. Neag; A.I. Torok; C. Tanaselia; I. Aschilean; M. Senila; Water, 2020, 12, 1614.

31. L. Belchinskaya; L. Novikova; V. Khokhlov; J.L. Tkhi; J. Appl. Chem., 2013, 789410, 1-9.

32. G. Cerri; A. Langella; M. Pansini; P. Cappelletti; Clays Clay Miner., 2002, 50, 127-135. 